\title{
S)
}

ISSN 2278 - 0211 (Online)

\section{Analysis of Heavy Metals in Tea Soil, Tea Leaves and Seagim Dam Water across the Seasons in Kakara District of Taraba State, Nigeria}

\begin{tabular}{c} 
Dr. Charles $\mathbf{M}$ \\
Associate Professor, Department of Chemistry, \\
Modibbo Adama University of Technology, Nigeria \\
Dimas BJ \\
Lecturer, Department of Science Education, \\
Taraba State University, Nigeria \\
Uwaisu M M \\
Researcher, Department of Chemistry, \\
Modibbo Adama University of Technology, Nigeria \\
\hline
\end{tabular}

\begin{abstract}
:
The levels of heavy metals were assessed in tea soil, tea leaves and Seagim dam water samples collected from Kakara tea estate, Taraba State. The concentration of heavy metals was determined by the use of AAS. The concentration of Ca, $\mathrm{Cd}, \mathrm{Co}, \mathrm{Cu}, \mathrm{Fe}, \mathrm{K}, \mathrm{Mn}, \mathrm{Ni}, \mathrm{Pb}$, and $\mathrm{Zn}$ in all the soil samples collected across the season ranged from [6.102-11.00],[0.0230.873],[0.029-0.058],[0.241-0.410],[0.900-1.958],[1.366-20.80],[0.263-0.496],[0.023-0.496],[0.018-0.068]and[0.110$0.275] \mathrm{mg} / \mathrm{kg}$, the concentration of $\mathrm{Ca}, \mathrm{Cd}, \mathrm{Co}, \mathrm{Cu}, \mathrm{Fe}, \mathrm{K}, \mathrm{Mn}, \mathrm{Ni}, \mathrm{Pb}$, and $\mathrm{Zn}$ in all the leaves samples collected across the season ranged from [0.982-3.566],[0.014-0.029],[0.010-0.071],[0.059-0.204],[0.066-0.755],[19.98-38.66],[0.106-0.369], [0.008-0.031], [0.006-0.099] and [0.080-0.199) $\mathrm{mg} / \mathrm{kg}$, the concentration of $\mathrm{Ca}, \mathrm{Cd}, \mathrm{Co}, \mathrm{Cu}, \mathrm{Fe}, \mathrm{K}, \mathrm{Mn}, \mathrm{Ni}, \mathrm{Pb}, \mathrm{and} \mathrm{Zn}$ in all the water samples collected across the season ranged from [9.029-13.74],[0.014-0.151],[0.063-0.114],[0.0900.204],[1.604-2.069],[3.013-6.711],[0.262-0.429],[0.058-0.112],[0.043-0.113] and [0.128-0.225] mg/dm3 respectively. The result analysis showed that the mean concentration of heavy metal was higher in wet season than in dry season and among the metals analyzed $K, \mathrm{Ca}$ and Fe were the most abundance in all the samples. The concentrations of heavy were found to belower than the maximum permissible level.
\end{abstract}

Keywords: Heavy metal, Tea leaves, tea soil, Seagim dam, season

\section{Introduction}

Recently, the toxicity and effect of trace heavy metals on human health and the environment has attracted considerable attention and concern. Among the heavy metals lead (Pb), cadmium (Cd), Astamine (As), and mercury (Hg) are especially toxic and are harmful to humans even at low concentration. Heavy metals can be introduced into the environment and consequently, living organisms through air, water, food or soil, but the degree of their concentrations depends on the type of heavy metals and the activities that occur in a particular area (Zaharaddeen et al., 2015). Several attempts have been made by many researchers to assess the quality of tea using chemical analysis. Metallic constituents of tea leaves are usually different according to the type of tea (green or black) and geographical sources (Fernandez-caceres et al., 2001; Sahito et al. 2005).

Tea is one of the most widely consumed beverages across the globe and is produced from the dried leaves of Camellia sinensis. Drinking tea might help reduce serum cholesterol, provide antiaging activities, and decrease the risks of both cardiovascular disease and cancer. However, heavy metal contaminants might accumulate during tea growth, transportation, packaging, and processing. Heavy metals are harmful to human health. These risks are recognized by the International Agency for Research on Cancer and the National Toxicology Program (Zhong et al., 2016).

To increase the optimum quantity of tea, tea planters applied sufficient amount of fertilizers on soil, and also used fungicides to control the herbs in the tea soil. But fertilizers and fungicides itself contain sufficient amount of heavy metals. Soil is a good medium, acting as a sink for natural and anthropogenic pollutants (Chakraborty et al., 2004). Humans are responsible for introducing heavy metals into the environment. Anthropogenic contamination with heavy metals is a worldwide problem that causes massive water and soil pollution (Caussy et al., 2003). Heavy metals that have contaminated industrial areas, roadside soils, riverbanks and urban areas are among the most serious environmental hazards (Magrisso et al., 2009). 
Heavy metal contamination in tea leaves has been documented. Lead concentrations in Chinese tea were found in a study with $32 \%$ of samples exceeding the national maximum permissible concentration (MPC) of $2.0 \mathrm{mg} / \mathrm{kg}$. An increasing trend in lead concentration on tea leaves was documented from 1989 to 2000. Proximity to highway and surface dust contamination was found to cause these elevated concentrations, as well as uptake of lead in soil by the roots of the tea plant. 44 up to $83 \%$ of teas have lead levels considered unsafe for consumption during pregnancy and lactation, as well as excessive levels of manganese and aluminum (Naik, 2015),

Sahito et al. reported the contents of 15 essential trace and toxic elements in some green tea samples and their infusion. Karimi et al. worked on the concentrations and health risks of metals in tea samples that were marketed in Iran.Zaharaddeen et al. (2015), determine the elemental composition of different brands of tea in Zaria markets in Nigeria and compare the result with the standard and provided both researchers and consumers with information on the mineral contents of different tea brands.

This paper aims to assess the levels of heavy metals in tea soil, tea leaves and Seagim dam water samples collected from Kakara tea estate, Taraba State. The modern agricultural practices which employed the use of organic fertilizers and pesticides residues (both herbicides and insecticides) generally exposes to the environment to heavy metals. Several attempts have been made by many researchers to assess tea quality by chemical analysis with reference to pigmentation and flavorings characteristics in other places. However, little work has been done to comprehensively screen the extent of bioaccumulation of heavy metals in tea leaves, tea soil and water in Kakara village of Sardauna Local Government Area of Taraba State, Nigeria.

\section{Materials and Methods}

\subsection{Study Area}

The study was carried out in the Mambilla plateau in Sardauna Local Government Area of Taraba State (Figure 1) which has an altitude of $1,800 \mathrm{~m}$ above sea level' the plateau forms part of the chain of the Adamawa and Mandara mountains is located between altitude $5030 \mathrm{o}$ to $7 \mathrm{o} 18 \mathrm{oN}$ and longitudes $10 \mathrm{o} 18 \mathrm{o}$ to $11 \mathrm{o}$ to $37 \mathrm{oE}$ has a land mass of $8,3865 \mathrm{~km}$. Kakara Dam or tea factory dam is a shallow fresh water dam situated on the floor of North east left valley in Nigeria The Kakara tea factory dam has a capacity of 10 million cubic meters and it is used to irrigate the tea farms, supplies untreated piped water to the local community, factory and electricity is also generated from the dam. The plateau has a near temperate climate with rainfall almost throughout the year Agbongiarnouyi et al., (2010).

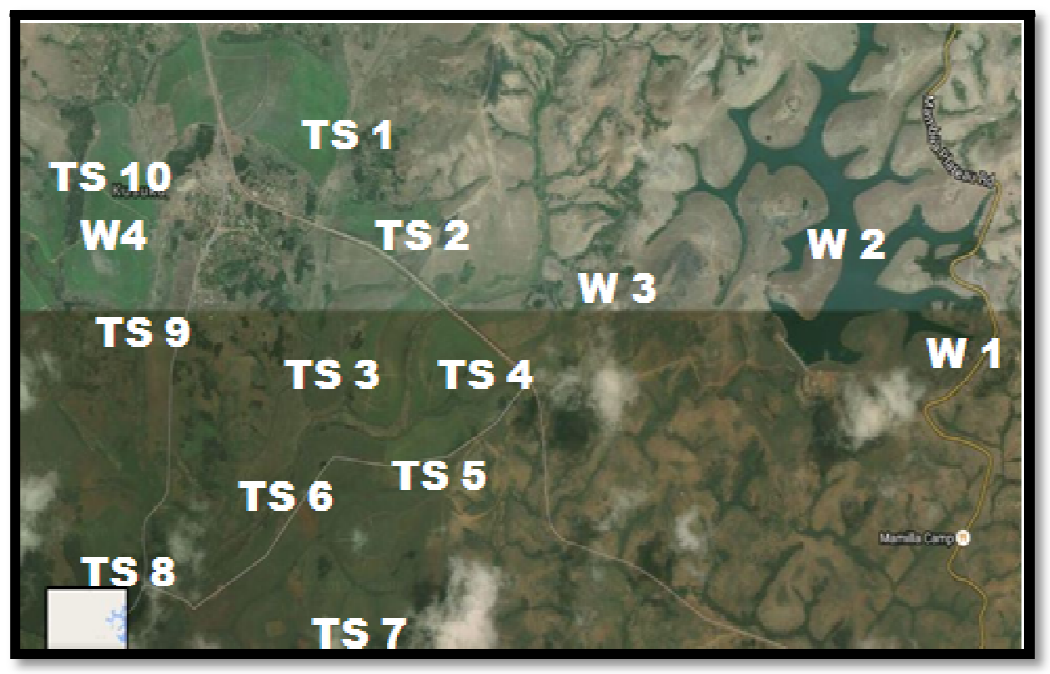

Figure 1: Map of a Study Area

Key Table

Source: Google, Wikipedia

W 1: Mouth of the Dam

W 2: Mid of the Dam

W 3: Outlet of the Dam

W 4: Tap water (Irrigation Farm)

T S. 1-10 are Tea Farms

\subsection{Materials /Instruments}

Digger, hammer and chisel, field bags for collection of samples, pestle and mortar, Bunsen burner, pH meter, tune cupboard, beakers, spatula, volumetric flask pipette, fitter paper, crucible, micrometer, mesh size sieve, stirring rod,multi water quality checker U-50 series, cat ion exchange AAS (Atomic absorption spectroscopy) buck scientific model 210 and oven etc. 


\subsection{Reagents/Chemicals}

Hydrochloric acid $(\mathrm{HCl})$ perchloric acid $\left(\mathrm{HClO}_{4}\right)$ de-ionies water, aqua regia (3:1) Hydrochloric acid; Nitric acid, sodium Hydroxide $(\mathrm{NaOH})$ calcium Hydroxide $\left(\mathrm{Ca}(\mathrm{OH})_{2}\right.$, EDTA Nitric acid, sulphuric acid $\left(\mathrm{H}_{2} \mathrm{SO}_{4}\right)$, Hydrogen peroxide $\left(\mathrm{H}_{2} \mathrm{O}_{2}\right)$.

\subsection{Sample Collection}

\subsubsection{Water Sampling}

Water sample was collected monthly from September, 2015 to February, 2016. Sampling was conducted at four pre-defined stations. One site in the plume area, one site was at the central part of the dam (mid dam), one site was at the outlet of the dam while other one site was at the consumption point (Tap) or irrigated farm site. Water temperature, $\mathrm{PH}$, conductivity and turbidity was measured in situ during each sampling occasion using PH Wagtech meter, turbidity meter (Ndugu, 2013).

\subsubsection{Sample Preparation}

The methods describe by Joseph et al., 2009 was adopted for the sampling and treatment of dam water, tea leaves and tea soil for elemental analysis of heavy metals using AAS.

\subsubsection{Water Sampling and Treatment for AAS}

One hundred $(100 \mathrm{ml})$ of highland Tea Dam water was collected and transferred into clean poly ethylene bottles. The water sample was filtered through filter paper and was kept at $4^{\circ} \mathrm{C}$ until analysis. $100 \mathrm{ml}$ of water was transferred into a large beaker $\left(750 \mathrm{ml}\right.$ capacity), and $15 \mathrm{ml}$ of conc. $\mathrm{HNO}_{3}$ was added to the mixture, and was allowed to evaporate on a steam bath to approximately $25 \mathrm{ml}$. Then transferred to50 $\mathrm{ml}$ acid washed volumetric flask and brought up to the volume with deionized water.

\subsection{Treatment/Digestion of Green Tea Leave for AAS}

The samples that were collected from the various farms were washed with tap water, followed by distilled water.Each sample was ground into a fine powder, sieve and were finally store in a capped plastic jar with an appropriate labeled. $1 \mathrm{~g}$ of air-dry leave was accurately weighed into $150 \mathrm{ml}$ beaker, $20 \mathrm{ml}$ conc. $\mathrm{HNO}_{3}$ was carefully added and allowed to stand for 1 hour; then $15 \mathrm{ml}$ of conc. $\mathrm{HClO}_{4}$ was carefully added and the mixture was allowed to stand on hot plate at about $200-225^{\circ} \mathrm{C}$ till the mixture turns to yellow or white. Digest was dissolved in $0.1 \mathrm{MHCl}$ and then filtered, and transferred into $150 \mathrm{ml}$ volumetric flask and made up to the mark. The sample solution was then filtered with a filter paper into polyethylene bottle and was taken for elemental analysis of heavy metals by using AAS.

\subsection{Digestion of Soil Sample for $A A S$}

One (1)g of air-dried soil, was accurately weighed into $150 \mathrm{ml}$ beaker, $20 \mathrm{ml}$ conc. $\mathrm{HNO}_{3}$ was carefully added and allowed to stand for 1 hour; then $15 \mathrm{ml}$ of conc. $\mathrm{HClO}_{4}$ was carefully added and the mixture was allowed to stand on hot plate at about $200-225^{\circ} \mathrm{C}$ till the mixture turns to yellow or white. Digest was dissolved in $0.1 \mathrm{MHCl}$ and then filtered, and transferred into $150 \mathrm{ml}$ volumetric flask and made up to the mark. The sample solution was then filtered with a filter paper into polyethylene bottle and was taken for elemental analysis of heavy metals and pesticide residue by using AAS and flame photometric analysis.

\subsection{Elemental Analysis}

The heavy metals ( $\mathrm{Cd}, \mathrm{Fe}, \mathrm{Pb}, \mathrm{Ni}, \mathrm{Zn}, \mathrm{Mn}, \mathrm{Co}, \mathrm{Cu}, \mathrm{Ca}$, and $\mathrm{K}$ ) were analyzed on each final solution by using buck scientific model 210 Atomic Absorption spectroscopy (AAS) as described Joseph et al., 2009.

\subsection{Data Analysis}

The Result that was obtained were analyzed statistically by using Excel, students' test and analysis of variations (ANOVA) for level of significance of variation between samples that were used to analyze the data.

\section{Results and Discussion}

\subsection{Results}

The mean Seasonal variation of heavy metals, some parameters and concentration across the locations are as presented below. Figure 2 shows the summary results of various metals concentration in tea soil samples collected during wet and dry Season from different tea estate. For wet season the concentration of Ca ranged from 6.756 to $11.000 \mathrm{mg} / \mathrm{kg}$, $\mathrm{Cd}$ ranged from 0.035 to $0.087 \mathrm{mg} / \mathrm{kg}$, the concentration of Co ranged from 0.042 to $0.058 \mathrm{mg} / \mathrm{kg}$. Cu concentration ranged from 0.288 to $0.410 \mathrm{mg} / \mathrm{kg}$, the concentration of Fe ranged from 1.343 to $1.958 \mathrm{mg} / \mathrm{kg}$, for K 2.470 to $20.80 \mathrm{mg} / \mathrm{kg}$, for Mn 0.338 to $0.496 \mathrm{mg} / \mathrm{kg}$, for $\mathrm{Ni} 0.047$ to $0.056 \mathrm{mg} / \mathrm{kg}$, for $\mathrm{Pb}$ ranged from 0.026 to $0.068 \mathrm{mg} / \mathrm{kg}$ and for $\mathrm{Zn} 0.149$ to 0.259 $\mathrm{mg} / \mathrm{kg}$. While for dry season the concentration of Ca ranged from 6.102 to $9.403 \mathrm{mg} / \mathrm{kg}$, Cd ranged from 0.023 to 0.049 $\mathrm{mg} / \mathrm{kg}$, the concentration of Co ranged from 0.029 to $0.046 \mathrm{mg} / \mathrm{kg}$. Cu concentration ranged from 0.241 to $0.388 \mathrm{mg} / \mathrm{kg}$, the concentration of Fe ranged from 0.882 to $1.802 \mathrm{mg} / \mathrm{kg}$, for K 1.366 to $7.212 \mathrm{mg} / \mathrm{kg}$, for Mn 0.263 to $0.455 \mathrm{mg} / \mathrm{kg}$, for Ni 0.042 to $0.042 \mathrm{mg} / \mathrm{kg}$, for $\mathrm{Pb}$ ranged from 0.018 to $0.029 \mathrm{mg} / \mathrm{kg}$ and for $\mathrm{Zn} 0.110$ to $0.225 \mathrm{mg} / \mathrm{kg}$. 
Figure 3 shows the result of heavy metals in tea leaves samples analyzed during wet and dry seasons at different locations. For wet season the concentration of $\mathrm{Ca}, \mathrm{Cd}, \mathrm{Co}, \mathrm{Cu}, \mathrm{Fe}, \mathrm{K}, \mathrm{Mn}, \mathrm{Ni}, \mathrm{Pb}$, and $\mathrm{Zn}$ ranges from 2.311 to $3.566 \mathrm{mg} / \mathrm{kg}, 0.017$ to $0.029 \mathrm{mg} / \mathrm{kg}, 0.022$ to $0.071 \mathrm{mg} / \mathrm{kg}, 0.087$ to $0.204 \mathrm{mg} / \mathrm{kg}, 0.139$ to $0.755 \mathrm{mg} / \mathrm{kg}, 16.02$ to $38.666 \mathrm{mg} / \mathrm{kg}, 0.127$ to 0.369 $\mathrm{mg} / \mathrm{kg}, 0.017$ to $0.031 \mathrm{mg} / \mathrm{kg}, 0.006$ to $0.099 \mathrm{mg} / \mathrm{kg}$ and 0.088 to $0.199 \mathrm{mg} / \mathrm{kg}$ for different farms respectively. And for dry season the concentrations of $\mathrm{Ca}, \mathrm{Cd}, \mathrm{Co}, \mathrm{Cu}, \mathrm{Fe}, \mathrm{K}, \mathrm{Mn}, \mathrm{Ni}, \mathrm{Pb}$, and $\mathrm{Zn}$ ranges from 0.982 to $2.680 \mathrm{mg} / \mathrm{kg}, 0.014$ to 0.021 $\mathrm{mg} / \mathrm{kg}, 0.010$ to $0.022 \mathrm{mg} / \mathrm{kg}, 0.059$ to $0.132 \mathrm{mg} / \mathrm{kg}, 0.066$ to $0.409 \mathrm{mg} / \mathrm{kg}, 19.989$ to $23.066 \mathrm{mg} / \mathrm{kg}, 0.106$ to $0.360 \mathrm{mg} / \mathrm{kg}$, 0.008 to $0.012 \mathrm{mg} / \mathrm{kg}, 0.008$ to $0.022 \mathrm{mg} / \mathrm{kg}$ and 0.080 to $0.170 \mathrm{mg} / \mathrm{kg}$ for different farms respectively.

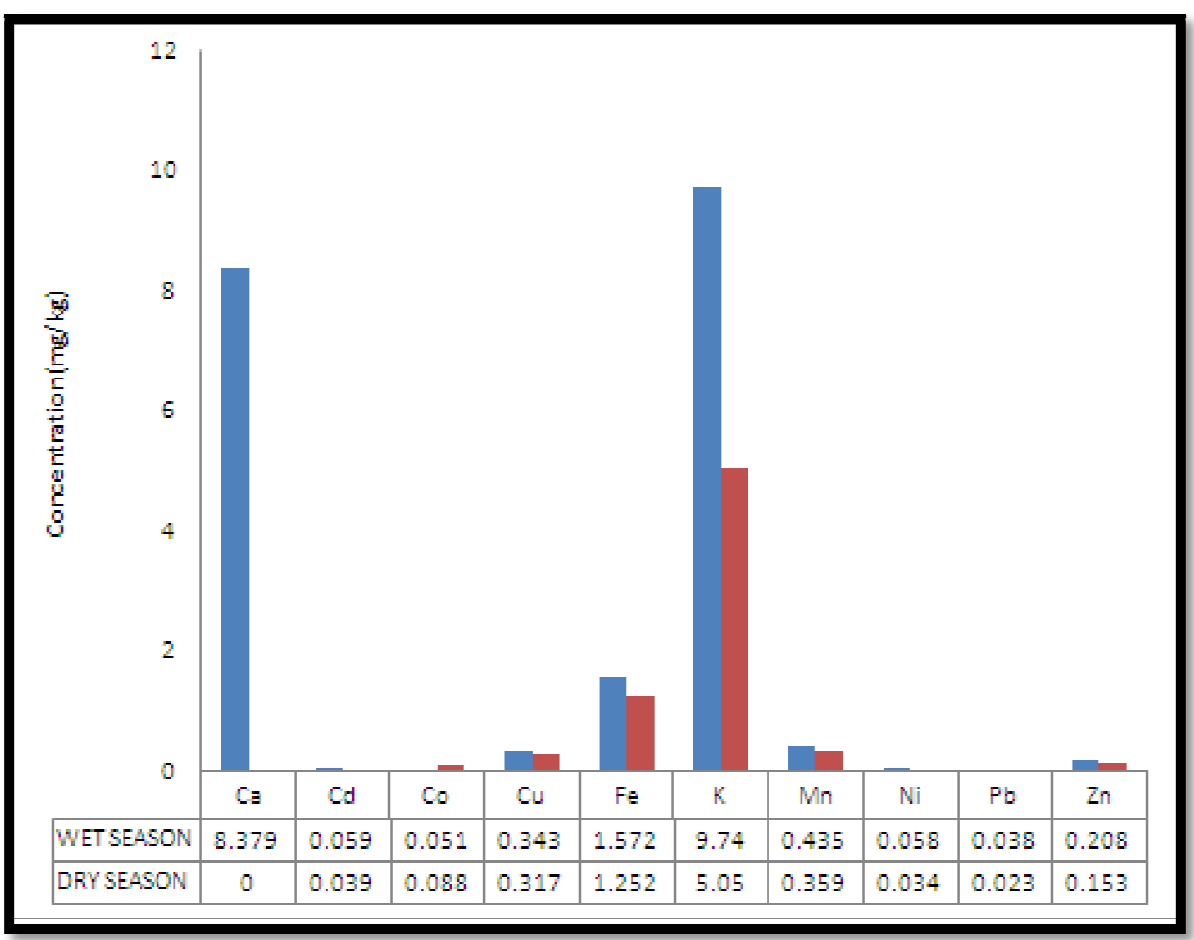

Figure 2: Seasonal Variation of Heavy Metals in Soil Samples Collected from Tea Farm, of Kakara Estateq

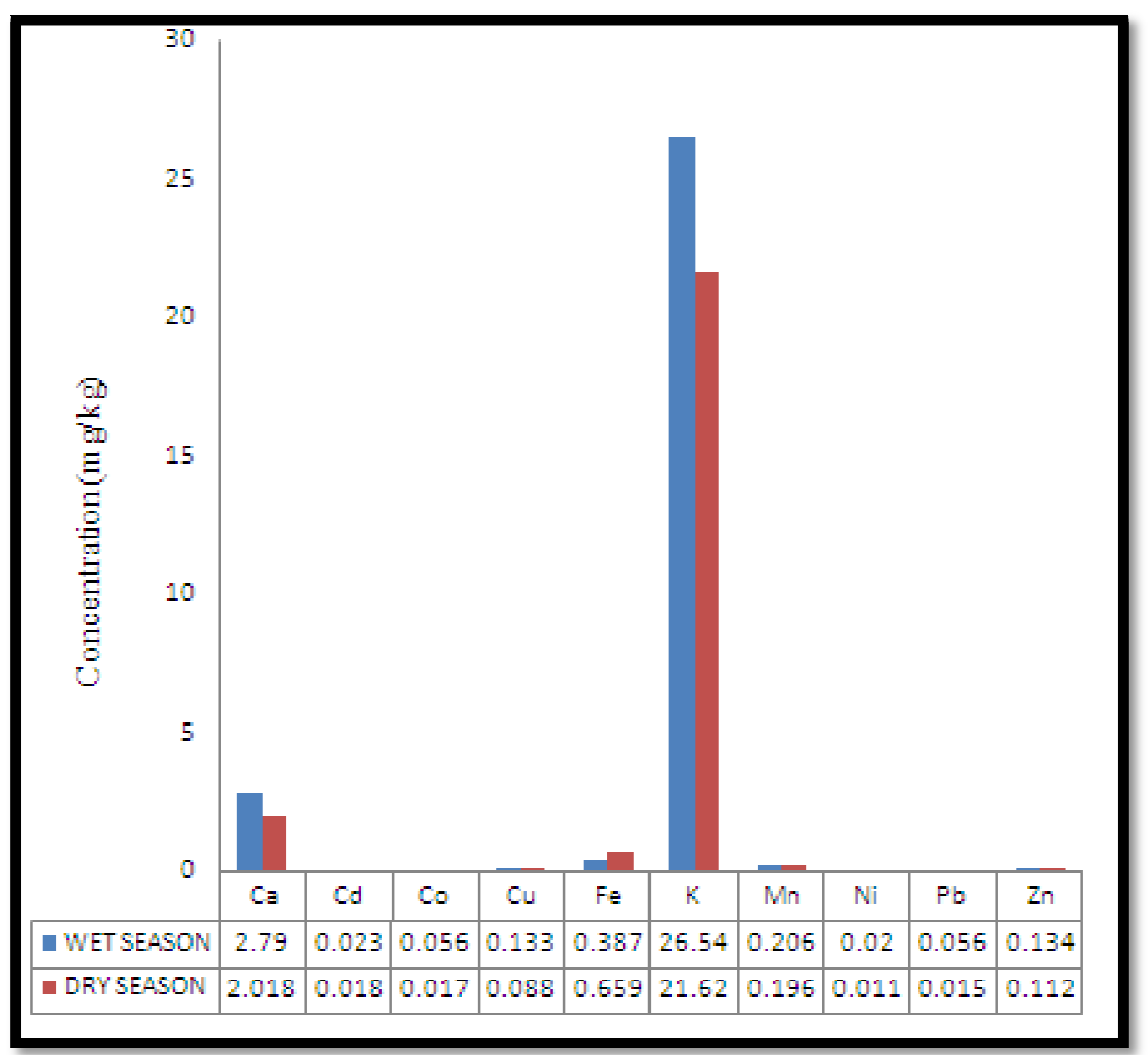

Figure 3: Seasonal Variation of Heavy Metals in Tea Leaves Samples Collected From Kakara Estates 
Figure 4: presents summary results of heavy metals concentration in Seagim dam water analyzed during the seasons. For wet season the concentration of $\mathrm{Ca}, \mathrm{Cd}, \mathrm{Co}, \mathrm{Cu}, \mathrm{Fe}, \mathrm{K}, \mathrm{Mn}, \mathrm{Ni}, \mathrm{Pb}$ and $\mathrm{Zn}$ ranges from 9.730 to $13.743 \mathrm{mg} / \mathrm{dm}^{3}$, 0.061 to $0.151 \mathrm{mg} / \mathrm{dm}^{3}, 0.092$ to $0.114 \mathrm{mg} / \mathrm{dm}^{3}, 0.177$ to $0.204 \mathrm{mg} / \mathrm{dm}^{3}, 1.790$ to $2.069 \mathrm{mg} / \mathrm{dm}^{3}, 3.036$ to $6.904 \mathrm{mg}^{3} / \mathrm{dm}^{3}$, 0.373 to $0.429 \mathrm{mg} / \mathrm{dm}^{3}, 0.070$ to $0.112 \mathrm{mg} / \mathrm{dm}^{3}, 0.021$ to $0.113 \mathrm{mg} / \mathrm{dm}^{3}$ and 0.125 to $0.225 \mathrm{mg} / \mathrm{dm}^{3}$.

For dry season the concentration of $\mathrm{Ca}, \mathrm{Cd}, \mathrm{Co}, \mathrm{Cu}, \mathrm{Fe}, \mathrm{K}, \mathrm{Mn}, \mathrm{Ni}, \mathrm{Pb}$ and $\mathrm{Zn}$ ranges from 9.029 to $12.580 \mathrm{mg}^{\mathrm{d}} \mathrm{dm}^{3}$, 0.014 to $0.148 \mathrm{mg} / \mathrm{dm}^{3}, 0.063$ to $0.102 \mathrm{mg} / \mathrm{dm}^{3}, 0.090$ to $0.211 \mathrm{mg} / \mathrm{dm}^{3}, 1.604$ to $2.048 \mathrm{mg} / \mathrm{dm}^{3}, 3.012$ to $6.794 \mathrm{mg}^{3} / \mathrm{dm}^{3}$, 0.262 to $0.401 \mathrm{mg} / \mathrm{dm}^{3}, 0.070$ to $0.112 \mathrm{mg} / \mathrm{dm}^{3}, 0.043$ to $0.102 \mathrm{mg} / \mathrm{dm}^{3}$, and 0.128 to $0.214 \mathrm{mg} / \mathrm{dm}^{3}$.

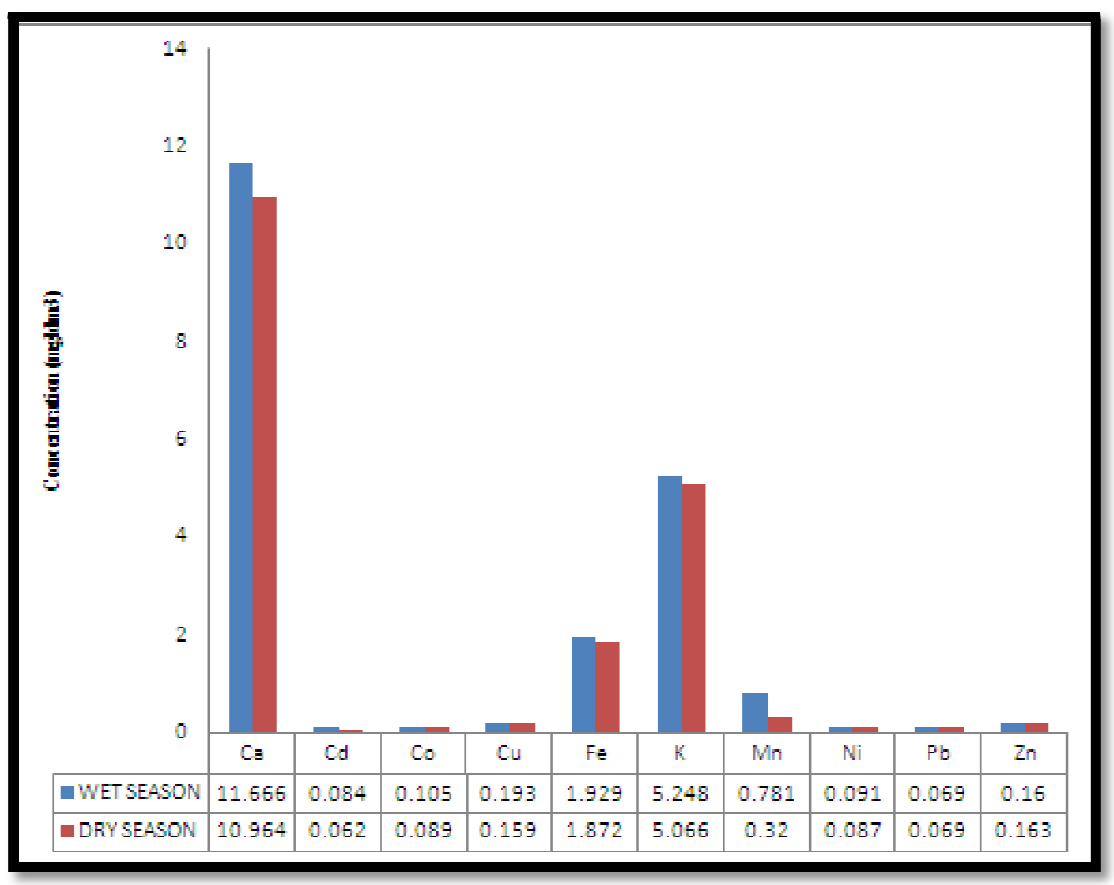

Figure 4: Seasonal Variation of Heavy Metals in Water Samples Collected from Seagim Dam Water Kakara Estate

From the result obtained the concentration of Ca is higher in water with a mean value of $11.666 \pm 1.643 \mathrm{mg} / \mathrm{dm}^{3}$, and then followed by Tea soil with Mean of $8.379 \pm 1.904 \mathrm{mg} / \mathrm{kg}$ and in tea leaves with a mean of $2.790 \pm 0.550 \mathrm{mg} / \mathrm{kg}$, during wet season. Also, in dry season from the result obtained Ca in water has a mean value of $10.964 \pm 1.51 \mathrm{mg} / \mathrm{dm} 3 \mathrm{and}$ less in tea leaves with a mean of $2.018 \pm 0.050 \mathrm{mg} / \mathrm{kg}$. These concentrations were lower as reported by Kazi et al., (1999) in tea leaves.

Similarly, for $\mathrm{Cd}$ the highest concentration was recorded in water with a mean $0.084 \pm 0.045 \mathrm{mg} / \mathrm{dm}^{3}$, $0.059 \pm 0.023 \mathrm{mg} / \mathrm{kg}$ for tea soil and $0.018 \pm 1.276 \mathrm{mg} / \mathrm{kg}$ was recorded in tea leaves during wet season, also in dry season, the value recorded for seagim dam water has a mean $0.62 \pm 0.059 \mathrm{mg} / \mathrm{dm}^{3}, 0.039 \pm 1.012 \mathrm{mg} / \mathrm{kg}$ for tea soil and $0.023 \pm$ $2.105 \mathrm{mg} / \mathrm{kg}$ for tea leaves. It is similar to the findings of Bansal, (2004) where concentration of these heavy metals is lower in dry season than that of wet season. According to the MOA standard (NY 659-2003), the Cd limit in tea is $1 \mathrm{mg} / \mathrm{kg}$. The concentration of $\mathrm{Cd}$ in all thesamples satisfied this criterion.

The level of Co in the samples were shown, from the result obtained Co has the highest concentration in wet season with means concentration of $0.105 \pm 2.944 \mathrm{mg} / \mathrm{dm}^{3}$ in water, $0.05 \pm 1.487 \mathrm{mg} / \mathrm{kg}$ in tea soil and $0.017 \pm 2.025 \mathrm{mg} / \mathrm{kg}$ in tea leaves. Similar for dry season Co recorded $0.089 \pm 0.018 \mathrm{mg} / \mathrm{dm}^{3}$ for water, $0.088 \pm 0.059 \mathrm{mg} / \mathrm{kg}$ in tea soil and $0.017 \pm 0.025 \mathrm{mg} / \mathrm{kg}$ tea leaves. The result obtained is lower than Xing and Chen, (2004) finding and also lower than the maximum permissible unit of heavy metals concentration in soil (ECDG, 2010). According to the WHO, the maximum permissible limit of cobalt is $1.5 \mathrm{mg} \mathrm{kg}^{-1}{ }^{17}$. The concentration of cobalt in all the tea samples in our study was ranged from 0.005 to $0.032 \mathrm{mg} \mathrm{kg}^{-1}$. By comparing results from our study with the maximum permissible limit in plants, cobalt was in values which correspond to the literature data.

The result show that the concentration of $\mathrm{Cu}$ was highest in wet season with a mean concentration of $0.193 \pm$ $0.00 \mathrm{mg} / \mathrm{dm}^{3}$ in water, $0.343 \pm 0.051 \mathrm{mg} / \mathrm{kg}$ in tea soil, $0.133 \pm 0.001 \mathrm{mg} / \mathrm{kg}$ leaves. In dry season the mean concentration of sample is $0.159 \pm 0.52 \mathrm{mg} / \mathrm{dm}^{3}$ in water, $0.0317 \pm 1.061 \mathrm{mg} / \mathrm{kg}$ in tea soil and $0.088 \pm 0.031 \mathrm{mg} / \mathrm{kg}$ in tea leaves. The result obtained showed lower value than those values reported by Saud and Al-Qud, (2003).Although Cu is an essential element forhuman health, excessive intake can impair organs and systems in the human body; hencethe maximal content of Cu in tea is limited in some regulations. According to the Industrial Standard (NY/T 288-2012) of China's Ministry of Agriculture (MOA), the $\mathrm{Cu}$ content is limited to $30 \mathrm{mg} / \mathrm{kg}$. The determined levels of $\mathrm{Cu}$ in this work were all below the limits.

The result obtained show that the mean concentration of $\mathrm{Fe}$ in the samples during a wet season $1.929 \pm$ $0.123 \mathrm{mg} / \mathrm{dm} 3$ for water, $1.253 \pm 0.445 \mathrm{mg} / \mathrm{kg}$ in Tea Soil and $0.387 \pm 0.279 \mathrm{mg} / \mathrm{kg}$ in Tea leaves. However, in dry season the mean concentration of Fe is $1.872 \pm 0.207 \mathrm{mg} / \mathrm{dm} 3$ in water, $1.252 \pm 0.445 \mathrm{mg} / \mathrm{kg}$ in Tea soil and $0.659 \pm 0.113 \mathrm{mg} / \mathrm{kg}$ in tea leaves.From the result obtained in comparing the value between the wet and dry season, the heavy metals are higher 
in wet season with exception of tea leaves during dry season which is higher than that of wet season and result obtained in this research is lower than reported by (Ansari et al., 2007).

Potassium which is the most common from these finding, $\mathrm{K}$ has mean concentration of $5.248 \pm 1.879 \mathrm{mg} / \mathrm{dm} 3 \mathrm{in}$ water, $9.74 \pm 2.021 \mathrm{mg} / \mathrm{kg}$ in tea soil and $26.54 \pm 2.35 \mathrm{mg} / \mathrm{kg}$ in tea leaves during wet season, while the mean concentration of $\mathrm{K}$ in dry season are $5.066 \pm 1.558 \mathrm{mg} / \mathrm{dm} 3$ in water, $5.050 \pm 2.560 \mathrm{mg} / \mathrm{kg}$ in tea soil and $21.623 \pm 1.82 \mathrm{mg} / \mathrm{kg} \mathrm{in}$ tea leaves. From the result obtained, comparing the value obtained between the wet and dry season, the heavy metals concentration is higher in wet season than in dry season.

The result obtained from this analysis show that $\mathrm{Mn}$ has a mean concentration of $0.781 \pm 0.439 \mathrm{mg} / \mathrm{dm}^{3} \mathrm{in}$ water, $0.435 \pm 0.022 \mathrm{mg} / \mathrm{kg}$ in tea soil and $0.206 \pm 0.113 \mathrm{mg} / \mathrm{kg}$ in tea leaves during wet season. Also, the mean concentration of $\mathrm{Mn}$ is $0.320 \pm 0.059 \mathrm{mg} / \mathrm{dm}^{3}$ in water, $0.359 \pm 0.086 \mathrm{mg} / \mathrm{kg}$ in tea soil and $0.196 \pm 0.112 \mathrm{mg} / \mathrm{kg}$ in tea leaves during dry season. Comparing the values of $\mathrm{Mn}$ in wet and dry season from this research it was found that the concentration is higher in wet season and also when compared with (Ansari et al., 2007), it is lower. Manganese is an essential metal nutrient for humans and other living organisms. Moreover, manganese is normally present in many kinds of foods and deficiency of manganese in humans appears very rare. The population of tea drinkers may have an increased intake of manganese than the general population because tea is an important source of manganese. Side effects of manganese can be from both overexposure or deficiency of this element. It can cause neurotoxic side effects when exceeding the homeostatic range 28,29 . According to Shah et al., the permissible limit of manganese in medicinal plants is $200 \mathrm{mg}$

The average concentration of $\mathrm{Ni}$ was determined in this research as $0.091 \pm 0.023 \mathrm{mg} / \mathrm{dm}^{3}$ in water, $0.058 \pm$ $0.004 \mathrm{mg} / \mathrm{kg}$ in tea soil and $0.020 \pm 2.676 \mathrm{mg} / \mathrm{kg}$ in tea leaves was analyzed during wet season, while in dry season the average concentration of $\mathrm{Ni}$ observed are $0.087 \pm 0.027 \mathrm{mg} / \mathrm{dm}^{3}$ in water, $0.034 \pm 2.7 \mathrm{mg} / \mathrm{kg}$ in tea soil and $0.011 \pm$ $1.916 \mathrm{mg} / \mathrm{kg}$ in tea leaves. The comparison of $\mathrm{Ni}$ in two seasons, show that the average of Ni in wet season is higher than that of dry season. Results obtained were lower than those described in the literature (Nath, 2013). Ni is nutritionally essential as a trace element for several animal species, microorganisms, and plants excessive Ni intake by consuming tea with $\mathrm{Ni}$ contents above a certain threshold is harmful to humans (Zhong et al 2016). Ni obtained in this research area is lower than those reported by Nookabkaew et al (2006) of black tea from Thailand whichhas value ranged from 2.28 $\mathrm{mg} / \mathrm{kg}$ to $9.19 \mathrm{mg} / \mathrm{kg}$. However, there are not enough regulations for the Ni levels intea.

The level of $\mathrm{Pb}$ in the samples were observed at a mean concentration of $0.069 \pm 0.039 \mathrm{mg} / \mathrm{dm}^{3}$ in water, $0.039 \pm$ $0.02 \mathrm{mg} / \mathrm{kg}$ in tea soil and $0.056 \pm 0.045 \mathrm{mg} / \mathrm{kg}$ in tea leaves during wet season, while during dry season the mean concentration of $\mathrm{Pb}$ in water is $0.069 \pm 0.029 \mathrm{mg} / \mathrm{dm}^{3}, 0.023 \pm 1.59 \mathrm{mg} / \mathrm{kg}$ in tea soil and $0.015 \pm 2.318 \mathrm{mg} / \mathrm{kg}$ in tea leaves. The $\mathrm{Pb}$ contents obtainedin this study were significantly lower than those determined by Al-0thman et al(2012), which ranged from $3.9 \mathrm{mg} / \mathrm{kg}$ to $8.7 \mathrm{mg} / \mathrm{kg}$ in the tea samples from Jazan and Jeddah, SaudiArabia. According to the limit for the $\mathrm{Pb}$ content in tea leaves stipulated by the Chinese National Standards (GB 2762-2012), the Pb maximum residue limits is $(5 \mathrm{mg} / \mathrm{kg}$ ). According to the WHO, the permissible limit of lead in plants is $10 \mathrm{mg} \mathrm{kg}$ -

The result of $\mathrm{Zn}$ is $0.160 \pm 0.045 \mathrm{mg} / \mathrm{dm}^{3}$ in water, $0.208 \pm 0.04 \mathrm{mg} / \mathrm{kg}$ in tea soil and $0.134 \pm 0.052 \mathrm{mg} / \mathrm{kg}$ in tea leaves during wet season while in dry season the average concentration of $\mathrm{Zn}$ is $0.163 \pm 0.042 \mathrm{mg} / \mathrm{dm}^{3} \mathrm{in}$ water, $0.153 \pm$ $0.05 \mathrm{mg} / \mathrm{kg}$ tea soil and $0.112 \pm 0.041 \mathrm{mg} / \mathrm{kg}$ in tea leaves. Zinc is considered as a relatively non-toxic metal, but with extremely high-level of intakes can cause nausea, vomiting, fatigue, lethargy, and epigastric pain According to the WHO, the permissible limit of zinc in plants is $50 \mathrm{mg} \mathrm{kg}$.

However, the average concentration of all metals was determined as mean value which appears to be quite high in water, then in tea soil and lower in tea leaves, with exception of $\mathrm{K}$ which is higher in the leaves and $\mathrm{PH}$ valve of the tea estate soil was found to be acidic. Generally, increase in heavy metals levels were observed in the samples during the wet season. The study shows that the level of heavy metal analyzed seasonally are within a safe limits or permissible limit as specified by the U.S FDA for edible plants part similar to food, soil and water from other part of the world (ECDG, 2010).

\begin{tabular}{|llll|}
\hline Water & Tea leaf & Tea soil \\
\hline Water & 1 & & \\
Tea leaf & 0.550 & 1 & \\
Tea soil & 0.396 & 0.985 & 1 \\
\hline
\end{tabular}

Table 1: Correlation Value of Heavy Metals in Relation between Water, Tea Leaf and Tea Soil

Table 1 shows the correlation result between the heavy metals in tea leaves and seagim water, it was found that the heavy metals in tea leaves and seagim water correlated negatively due to correlation value of 0.396 . The correlation of heavy metals in tea soil and tea leaves correlated positively and significantly with tea soil and tea leaves due to the correlation value of 0.985 and finally, the correlation of heavy metals in seagim water and tea soil was positively and significantly with seagim water and tea soil due to the correlation value of 0.550 . Therefore, there was positive correlation between seagim water and tea soil. The result shows the ability of these samples accumulating with heavy metals, the concentration of pollutants was maximum in wet season, thus indicating an increase in heavy metals levels in the rainy season over those in the dry season. This may be attributed to the possibility of the runoff from the surrounding farm containing metal salts being washed into the sample site, or application of fertilizes, animal wastes and herbicides to improve the tea productivity during rainy season.

\section{Conclusion}


Potassium, Calcium and Iron were most abundant metals analyzed in the samples. The result shows that the heavy metals concentration in almost all the samples analyzed were found to be higher in wet season than in dry season. The level of heavy metals in the sample analyzed was below the permissible limit but since there can be bioaccumulation of these elements resulting in toxicity, routine monitoring is advisable.

\section{References}

i. Agbongiarnouyi A.E and Daniel M.A, (2010): Gender contribution of highland tea fieldagronomic practices in Taraba State. Cocoa Research Institute of Nigeria. Int. J Sustain. Crop Prod. 5(4): 71-75.

ii. Al-Othman ZA, Yilmaz E, Sumayli HMT, Soylak M (2012). Evaluation of trace metals in tea samples from Jeddah and Jazan, Saudi Arabia by atomic absorption spectrometry. BEnviron Contamination Toxicology, 89:1216.

iii. Ansari, F., Norbaksh, R. and Daneshmandirani, K. (2007) Determination of heavy metals in Iranian and imported black tea. Iranian Journal of Environmental Health, Science and Engineering, 4(4), 243-248.

iv. $\quad$ Bansal, O.P. (2004): Uptake of heavy metals by crops plants. 23. 501-506.

v. Chakraborty, Rahul, Dey, Dkhar, S., P. Tibah, R.C., Myrboh, B., Ghosh, and Sharma, D.K.(2004): Determination of few heavy metals in some vegetable from North Eastern Region of India in relation to Human Health. Pollution Research. (India). 23 (3). 549-554.

vi. Caussy, D., Gochfeld, M., Gurzau, E., Neagu, C. and Ruedel, H. (2003): Lessons for case studies of metals: investigating exposure, bioavailability and risk. Ecotoxicology and Environment Safety.

vii. Fernandez-Caceres, P. M. J., Martin, M. P. \& Gonzalez, A. G. (2001). Differentiation of tea(Camellia sinensis) varieties and their geographical origin according to their metalcontent. J. Agric. Food Chem., 49, 4775-4779.

viii. Joseph et al (2009). Manual of soil, plants \& water analysis. pp77-127

ix. Fernandez-Caceres, P. M. J., Martin, M. P. \& Gonzalez, A. G. (2001). Differentiation of tea (Camellia sinensis) varieties and their geographical origin according to their metal content. J. Agric. Food Chem., 49, 4775-4779.

X. Karimi, G., Hasanzadeh, M.K., Nili, A., Khashayarmanesh, Z., Samiel, Z., Nazari, F. (2008).Concentrations and Health Risk of Heavy Metals in Tea Samples Marketed in Iran. Pharmacologyonline 3: 164-174.

xi. Kazi, T. G., Kazi, G. H. \& Ansari, T. P. (1999). Biorecycling of trace and toxic elements indifferent vegetables from sludge samples used as agricultural fertilizer. ACGC Chem.Res. Comm., 9, 51-56.

xii. Magrisso, S., Belkin, S., Erel, Y. (2009): Lead Bioavailability in Soil and Soil Components, Water Air. Lead Bioavailability in Soil and Soil Components. Water, Air and SoilPollution 202(1):315-323.

xiii. MOA (2003). Industrial Standards of the Ministry of Agriculture of the People's Republic ofChina. Residue limits for chromium, cadmium, mercury, arsenic and fluoride in tea. NY659-2003.

xiv. Nath. T.N (2013). Determination of heavy metals and its impacts on tea cultivated soil and tealeaves in Dibrugarh district of Assam Indian journal of advance research.

xv. Naik N. (2015). Metals contamination of tea estates soil in Sivasagar and Dibrugarh districts ofAssam, India. international Journal of Advancements in Research \& Technology, 2: (4),216-235.

xvi. Ndugu, J., Augustine D. C. M. Hulchers, S.Y.H. Kitaka and Mathooko, J. (2013). Spatiotemporal variation in the tropic status of lake Naivash, Kenya. Lakes and reservoirs : research and management, 18(4), 317-328.

xvii. Nookabkaew S, Rangkadilok N, Satayavivad J. (2006). Determination of trace elements in herbaltea products and their infusions consumed in Thailand. J Agr Food Chem. 54:6939e44.

xviii. Sahito, S. R. et al. (2005). The contents of fifteen essential, trace and toxic elements in somegreen tea samples and in their infusion. Tour. Chem. Soc. Pak., 27(1), 43-47.

xix. Saud.S. \& Al-Qud (2003). Heavy metals in tea and herbs leaves. J Biol sci 6:208-213.

xx. Seenivasan S, Manikandan N, Muraleedharan NN. (2008). Chromium contamination in black teaand its transfer into tea brew. Food Chem. 106:1066-9.

xxi. William C.H \& David (1976). Study on accumulation in soils of Cd, residues from phosphates fertilizers and their effects on Cd contents of plants soil science 121:86.93.

xxii. Zaharaddeen N. Garba, Saiydah Ubam, Aliyu Abubakar Babando, Ahmad Galadima (2015).Quantitative Assessment of Heavy Metals from Selected Tea Brands Marketed in Zaria,Nigeria. Journal of Physical Science, Vol. 26(1), 43-51.

xxiii. Zhong W, Ren T, Zhao L (2016). Determination of Pb (Lead), Cd (Cadmium), Cr (Chromium),Cu (Copper), and Ni (Nickel) in Chinese tea with high-resolution continuum source graphite furnace atomic absorption spectrometry. Journal of food and drug analysis. Vol.24, pp $46-55$. 